\title{
FACTORS AFFECTING THE PERFORMANCE OF AGRI SMALL AND MEDIUM ENTERPRISES WITH EVIDENCE FROM KOSOVO
}

\author{
Ekrem Gjokaj ${ }^{1}$, Diana Kopeva², Nol Krasniqi ${ }^{3}$, Henrietta Nagy ${ }^{4}$
}

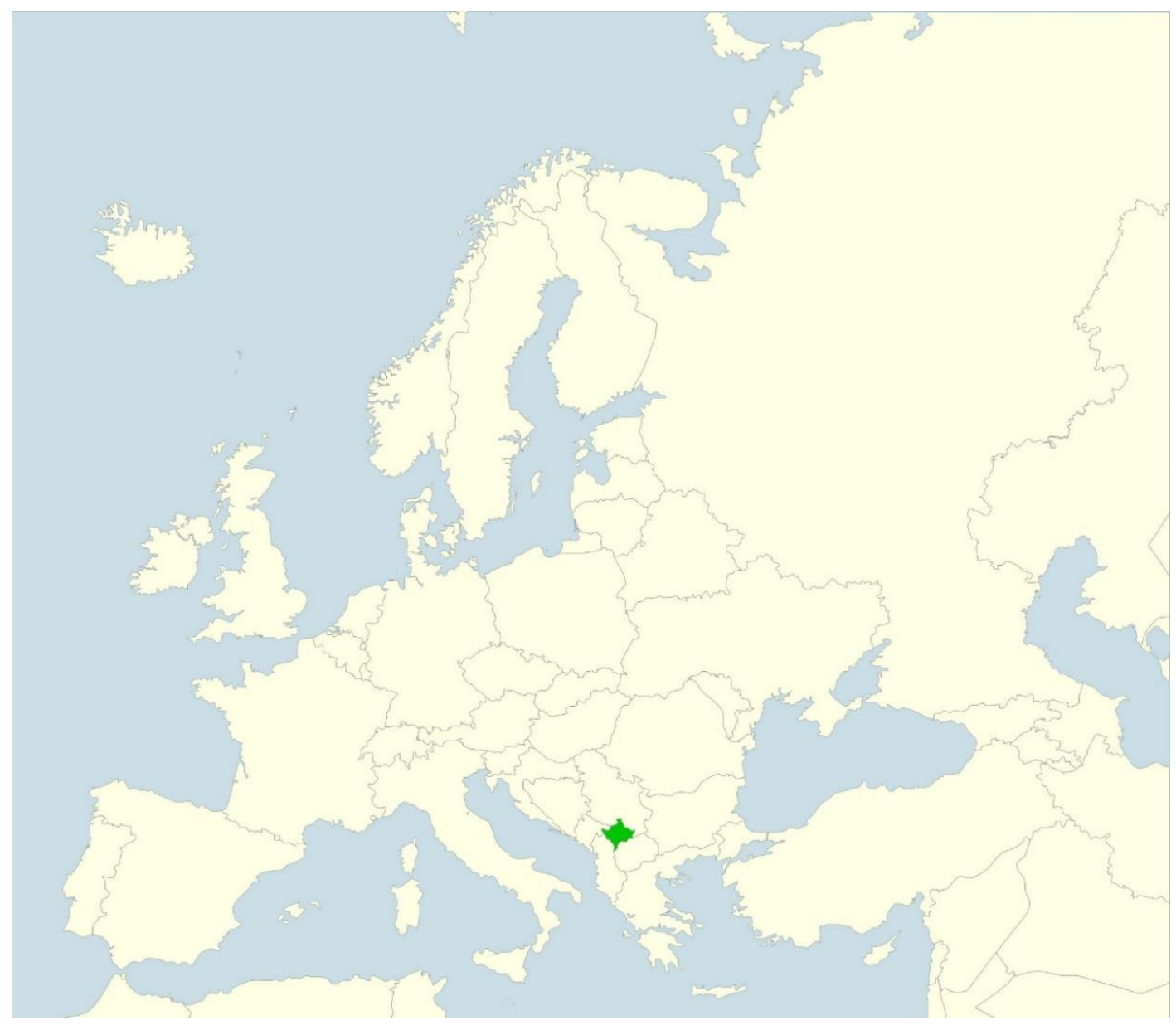

\footnotetext{
1 Ekrem Gjokaj, Faculty of Life and Environmental Sciences, University "Ukshin Hoti" Prizren, Kosovo; e-mail: ekrem.gjokaj@uni-prizren.com, ORCID: 0000-0002-1649-4098

2 Diana Kopeva, University of National and World Economy, Sofia, Bulgaria; e-mail: dkopeva@unwe.bg, 0000-0001-51460793

${ }^{3}$ Nol Krasniqi (corresponding author), Faculty of Life and Environmental Sciences, University “Ukshin Hoti” Prizren, Kosovo; e-mail: nol.krasniqi@uni-prizren.com, ORCID: 0000-0003-4570-3239

${ }^{4}$ Henrietta Nagy, Kodolányi János University, Budapest, Hungary; e-mail: nagy.henrietta@kodolanyi.hu, ORCID: 00000001-9732-9926
} 
Abstract: The agri SMEs in Kosovo are facing challenges that are reducing competitiveness and preventing it from fulfilling their production potential. The main constraints in increasing productivity and improving competitiveness are the low use of modern techniques and technologies in both production and management of enterprises, lack of funds, the low use of inputs, and the limited ability to meet international standards of food safety. This paper is focused on the analysis of the impact of agricultural SMEs in the rural economy of the country and the problems related to the impact. The data used for this analysis are the data conducted for the Farm Structure Survey (FSS) which includes the farmers' list from Agricultural Records compiled by the Kosovo Agency of Statistics (KAS) in 2014, as well as the lists of beneficiaries for both direct payments/subsidies and for grants for the period of 2014 to 2017 received by the Agency for Agriculture Development. From the research results, significant factors having an effect on the annual income of agris SMEs are the following: income from the sale of agricultural products, income from subsidies, income from non-agricultural activities, income from salaries, remittances, and income from other activities.

Key words: SME, enhancing, constrains, sustainability, rural development, economic growth

\section{Highlights:}

- Agri SMEs play crucial roles in income sources, hence the processing industry and foodproduct processing constitutes the largest part of financial turnover.

- Labour-intensive horticulture and livestock are traditional economic activities of agri SMEs in Kosovo.

- Agri SMEs employ many people, including skilled and unskilled work, enabling income distribution from a broad macroeconomic perspective.

- Significant factors that affect the annual income of agri SMEs are: Income from the sale of agricultural products; Income from subsidies; Income from non-agricultural activities, salaries; remittances; Income from other activities.

- There is a strong positive link between 'income from the sale of agricultural products' and 'income from subsidies'.

\section{Introduction}

Over recent years, Kosovo recorded economic growth rates among the highest in the region, but the growth has not attained the levels or breadth necessary to allow the country's full potential to be developed or for it to accelerate off of the current plateau of development. Instead, the growth was based on a specific development model consisting of two pillars. The first pillar is large remittances and FDI inflows from diasporas that boost domestic demand through household consumption, while the core of the second pillar is a high level of public investment. The resulting economic structure is characterized by high levels of consumption and investment in non-productive sectors (mainly construction), but on the other hand, one of the least diverse export baskets in the region, comprising almost solely of low value-added goods (ERP, 2016). The combination of high consumption and low exports has resulted in very high trade deficits. Given the risks associated with such a development model, the main challenge for Kosovo is to establish conditions conducive to self-sustained growth based on increased domestic productivity and export competitiveness and aimed at reducing high unemployment and poverty (ERP, 2016). Weak contract enforcement, which also has a negative impact on access to finance, remains a binding constraint and is being addressed by reform measures aiming to strengthen the property rights system and increasing judicial efficiency, the latter 
specifically focusing on the economic development, especially regarding the agriculture sector (Gjokaj. E, Halimi, K. Xhabali, V. Imami, D. Gjonbalaj, M., 2017). Regardless of the permanent investments in the agriculture sector, Kosovo is still facing negative trade deficit of agriculture products. Imports of agricultural products remain relatively high, accounting for about $10 \%$ of all imports (ERP, 2018). Out of this amount, 30\% consists of food and food products. Kosovo is one of the largest importers of food per capita in Europe (ERP, 2018). The continued slow growth in primary production is directly reflected in the agri-food industry, and as a result, the agri-food industry is quite fragmented. The overall range of activities related to the production of food, beverages, animal and crop production, hunting and related services represent one of the biggest sectors in the economy of Kosovo. Agriculture SMEs in Kosovo are facing a full array of systemic and structural challenges that need to be addressed by the central and local governments and other involved actors in order to attain their competitive potential and economic growth. Despite these issues, Kosovo has 1,1million ha land out of which $53 \%$ is agricultural land (out of which $54.3 \%$ belong to permanent grasslands, $43.6 \%$ arable land, $1.9 \%$ permanent crops and $0.3 \%$ kitchen garden), $41 \%$ are forests, $6 \%$ belong to other land uses (KAS, 2015). Furthermore, the agriculture sector is the largest employer in Kosovo and generates $34 \%$ of total employment. It contributes to the GD with about $10.3 \%$, and $17.6 \%$ of the total export value comprises agricultural products (MAFRD, 2019). Labour-intensive horticulture and livestock are traditional economic activities of agri SMEs in Kosovo, representing a strong rural cultural identity. There is a preference among the farming communities to remain engaged in these subsectors for their livelihood (Kostov, P. Davidova, S. Bailey, A. Gjokaj, E. Halimi, K., 2020). Most of the landholdings in Kosovo are small and fragmented with an average landholding size ranging between 1.5 and 2.0 ha, which is further aggravated by a constant conversion of agricultural land into residential or industrial plots. This results in low production volumes per farmer. With limited access to modern technologies, good quality inputs, irrigation, postharvest management and processing infrastructure, investments in agricultural production remain small. There is a general lack of functional farmer's cooperatives or other forms of farmers' production groups, due to difficulties in accessing credits and markets (Muriqi, S., Fekete-Farkas, M., \& Baranyai, Z., 2019). Although there is a legal provision for Public-Private Partnerships which can help to improve farm productivity, employment, and revenues, PPPs have yet to be used extensively in the country.

The prospects for the agriculture sector have improved with the recent EU membership prospects and free market access to the EU through the Stabilization Association Agreement (SAA) and the Central European Free Trade Agreement (CEFTA). This offers Kosovo opportunities for sustained development in the agriculture sector. In this way, the recent inclusion of Kosovo in the CEFTA provides not only opportunities but also a huge challenge for the food value chain actors to cope with quality and safety standards and thus of being competitive with standards and market prices prevailing in the EU. Currently, only a very small proportion of farms and processors can enter the EU market (Erjavec, E. Tina, V. Rednak, M. Ciaian, P. \& Lazdinis, M., 2020). Several factors prevent the achievement of sufficient scale of economic growth and therefore they result in predominant non-competitive forms of farming. The success of farming and food processing depends very much on the entrepreneurs on the farms and in the agri-industries. However, to become really successful all entrepreneurs need a friendly, stable and predictable business environment conductive to growth. It is definitely the combined efforts of national and local governmental organizations, which have the capacity and - in view of Kosovo's need for development acceleration - which are in charge of creating this environment for the entire agribusiness sector, which comprises the business activities performed from farm to fork (Erjavec, E. Lovec, M., 2017). It must not be seen as an expensive or selfless task as a business-friendly environment creates wealth, jobs and delivers taxes back to the government (FAO, 2013), (Alarcón, S., \& Sánchez, M, 2013). In Kosovo, the factors considered as being the most persistent and challenging on development acceleration for agribusiness and agri-industries are many, including; the low availability of skilled human resources in agri SMEs; lack of technologies; inadequate infrastructure facilities and utilities; insufficient or difficult to access storage capacities; limited availability of appropriate rural and agricultural finance (there is often a lack of financial products tailored to the specific risks and cash flow patterns of 
agricultural enterprises); lack of financial, linkages among business partners in the form of working groups, cooperatives or clusters etc. Despite this array of problems, challenges, and difficulties faced by Kosovo agriculture enterprises, these enterprises still represent the main factor and the best potential avenue for economic growth in the rural economy, and they are playing an important role in the gradual economic development of Kosovo. At least in the near -and medium-term future, after, they are the main source of new jobs and income generation (Gjokaj, E. Leeds, S. Halimi, K., 2018).

\section{Theoretical background}

\subsection{Definition of Rural in Kosovo}

Since Kosovo has a very high population density of 166 persons per $\mathrm{km}^{2}$ on the one hand and on the other hand the NUTS ${ }^{5}$ system has not yet been introduced. Therefore, the OECD's methodology is currently not suitable for the definition of rural areas (MAFRD, 2013).

The definition of "rural areas" used by the Kosovo Agency for Statistics (KAS) for the "Kosovo Population and Housing Census 2011' and other statistics is "a non-urbanized geographical area defined at settlement level - characterized by a lower population density and typically where much of the land is devoted to agriculture in comparison to surrounding areas". Referring to that Kosovo Population and Housing Census (2011), an area is defined as rural by administrative decision of the municipality. Using this definition and referring to the Figure 1, (94.3\%) the entire territory of Kosovo or $1,028,963$ ha, was recognized as rural areas, and it contained $62 \%$ of the population out of the total number of $1,078,239$ inhabitants (KAS, 2012). Whereas, for the ARDP ${ }^{6} 2014-2020$ context, settlements with a population above 30,000 inhabitants, which are the cities of Pristina, Prizren, Gjilan, Peja, Mitrovica, Ferizaj and Gjakova, are classified as urban areas, while the rest of the territory of Kosovo is considered as rural areas (MAFRD, 2013).

Regarding income sources the data presented in Table No. 1 shows that the public sector is the most important source of income in Kosovo and is the main source for almost a quarter of all households. The second most important source is wages from the private sector, followed by pensions with $13 \%$, and while an important source of income is money sent from abroad (remittances) with $9 \%$. According to the household survey carried out most recently by the UNDP in 2012, the average monthly income per household is $€ 546$ plus $€ 29$ from remittances. Dependency on remittances in Kosovo remains substantial, with more than $20 \%$ of households reporting reliance on remittances, a share that is even higher among households in rural areas and those headed by women (UNDP, 2013).

Although comparing with the data prepared for Kosovo's Economic Reform, the agri SMEs play crucial roles in income sources, hence the processing industry (food-product processing) constitutes the largest share of financial turnover or $50 \%$, whereas the processing of beverages participates with $25 \%$. Besides processing industry, other important business activities are also the crop and animal production, hunting and related services with a turnover of $15 \%$, production of wood, wood products and cork participates with $9 \%$ and fishing with aquaculture with 1\% (ERP, 2016), Kosovo is a landlocked country, and so fishing and aquaculture is largely confined to Kosovo's lakes. However, Kosovo industry continues to face low level of competitiveness due to internal and external factors like, weak cooperation and coordination between companies through industry associations which do not perform well, as well as the poor educational and research institutions that would have supplied the SME sector with relevant business knowledge (Muriqi, S. Baranyai, Z. Fekete-Farkas, M., 2020). Also, the lack of certification of products and production processes deemed to hamper efforts for the integration of local groups in the SME sector in general (Gjokaj. E, Halimi, K. Xhabali, V. Imami, D. Gjonbalaj, M., 2017). Poverty among the rural population is higher than in the urban population,

\footnotetext{
${ }^{5}$ Nomenclature of territorial units for statistics

${ }^{6}$ Kosovo's National Agriculture and Rural Development Program prepared in line with the CAP IPARD program based on the 3 main objectives and 6 priorities of the EU rural development policy
} 
and according to estimations, about 40 per cent of the work force is unemployed. Most of the labour force in rural area is unskilled or semi-skilled and the lack of job opportunities is putting a strain on social cohesion and encouraging out-migration (ERP, 2016).

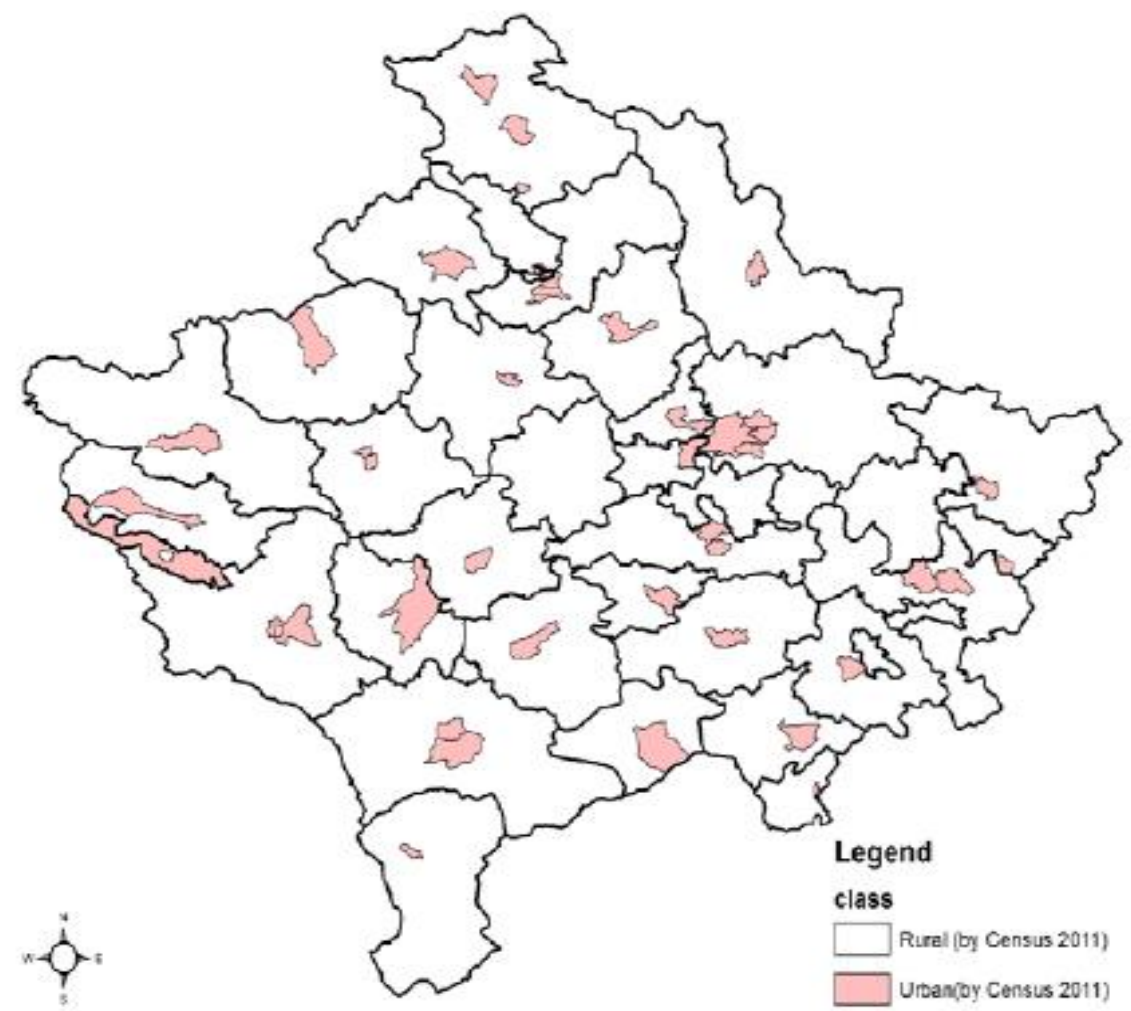

Fig 1. Map of rural and urban areas according to KAS definition for Kosovo. Source: KAS Census 2011

Tab 1. Main sources of household income in Kosovo, in \%. Source: KAS: Results of Household Budget Survey 2016

\begin{tabular}{lc}
\hline Sources of income & 2015 \\
\hline Salaries and wages from the public sector & 26 \\
Salaries and wages from the private sector & 22 \\
Pensions & 13 \\
Other household businesses & 11 \\
Money sent from abroad (remittances) & 9 \\
Income from temporary activities & 6 \\
Agriculture & 5 \\
Social benefits - 1st category & 4 \\
Social benefits - 2nd category & 1 \\
Money sent from Kosovo & 1 \\
Income from property & 1 \\
Other & 1 \\
\hline Total in \% & 100 \\
\hline
\end{tabular}

As stated and as shown in Table 1 in most cases, agriculture forms only part of rural households' incomes; most families depend on remittances from abroad to supplement their farming incomes. It is estimated that an average of 48 per cent of the rural household budget is used for consumption of food and non-alcoholic beverages, leaving little space for either other necessities or for discretionary spending and leisure (MAFRD, 2019). Based on official statistical data published by Kosovo's Agency 
of Statistics (KAS) and Kosovo Business Registration Agency (KBRA), only in 2019, the number of new entrants to the labour market in our economy is significantly high with more than ten thousand new SMEs, so in this context, the accelerated development of SMEs in the field of agribusiness will significantly affect creating new jobs, as well as enabling a balanced economic development of the country (Weidinger, C. Fischler, F. Schmidpeter, R., 2014). Additional reasons for this research are the findings in the $\mathrm{EC}^{7}$ progress report for Kosovo, which emphasizes the fact that despite economic growth, the country's economy is still not able to create sufficient jobs to absorb the inflows of new, which would reduce the pressure on the labour market $(E C, 2018)$.

This research intends to echo the findings of that EC report and to support the idea that establishing new SMEs as well as retaining and expanding existing ones would contribute to economic growth and job creation. If we add to these arguments the fact that agri SMEs perform many functions for the societies and economies of countries around the world, then their promotion is considered one of the most important issues in those countries (Weidinger, C. Fischler, F. Schmidpeter, R., 2014). Even in Kosovo, SMEs represent a large share of economic activity; they also perform a stabilizing function in society. At the same time, SMEs employ many people, including skilled and unskilled work, enabling income distribution from a broad macroeconomic perspective. Therefore, supporting SMEs is related to addressing the main challenge in rural areas and the nation as a whole - i.e. unemployment.

However, according to economic laws, there is a correlation between real growth and unemployment rate, i.e., Okun's Law, regarding the relationship between real growth rate and unemployment rate, respectively. If the real annual GDP growth is about 2.7 per cent, then the Unemployment rate will remain constant, while in case the growth rate is above the trend rate of $2.25 \%$, the unemployment rate falls. Furthermore, for every $1 \%$ increase in real GDP over the course of a year, the unemployment rate falls by $0.5 \%$ (Edward,S. Knotek, II., 2007) (Dixon, R. Lim, G.C. Van Ours J.C., 2016). Based on this theory and taking into account the flow rate of GDP growth in Kosovo in the last three years, namely 2017, 2018, 2019, the results show that this increase does not even ensure the maintenance of unemployment at such high levels let alone alleviating unemployment.

In a perfect business environment, agri SMEs can grow into large firms, changing the transition game from local to global. However, even if enterprises remain small or medium in size, they can still create significant revenue opportunities for their owners and employees and generate new revenue through tax collection for government tax authorities. All this is achieved through increased productivity in the enterprise and the sale and/or supply of increasingly valuable goods and services.

It is important to note that a company, no matter how successful it is, still not able to compete if it stands alone (Weidinger, C. Fischler, F. Schmidpeter, R., 2014). Therefore, based on this principle, the government of the country and other relevant institutions should all work together to create favourable conditions for the proper development of SMEs. Furthermore, agri SMEs are part of the dynamic value chain and increase employment opportunities, which will contribute to income growth, rising living standards, and improving living condition in general (McAdam, M., McAdam, R., Dunn, A., \& McCall, C., 2016) (Panasyuk M.V. Safiullin L.N. Gafurov I.R. Safin A.R., 2014).

\subsection{Research objectives}

The main objective of this paper is to analyse the impact of agricultural SMEs in the rural economy of the country and to define the problems related to that impact. We will try to figure out the measures related to income sources, the outcome of the production cost and profitability analyses, profitability indicators and return of investments of Agri SMEs, In order to achieve the paper objectives, we used the data conducted for the Farm Structure Survey (FSS) which includes the farmers' list from Agricultural Records compiled by the Kosovo Agency of Statistics (KAS) in 2014, as well as the lists

\footnotetext{
${ }^{7}$ European Commission
} 
of beneficiaries for both direct payments/subsidies and for grants for the period of 2014 to 2017 received by the Agency for Agriculture Development.

\section{Materials and Methods}

\subsection{Materials Study Area and Sample Selection}

The research is focused on the analysis of the impact of agricultural SMEs in the rural economy of the country and the problems related to the impact. The design used in this research includes calculations related to the research of profitability indicators and return of investments in the company, as well as productivity multi-factors. The sample of farms and farmers was selected in close cooperation and coordination with the ministry staff for the Farm Structure Survey (FSS) purpose, and it includes the farmers list from Agricultural Records compiled by the Kosovo Agency of Statistics (KAS) in 2014, as well as the lists of beneficiaries for both direct payments / subsidies and for grants from 2014 to 2017 received by the Agency for Agriculture Development. The list of beneficiaries for direct subsidies included 26,274 beneficiaries, whereas the list of grant beneficiaries included 1,562 farmers. In addition, 1,081 non-beneficiaries of subsidies were identified (Table 2). Initially, filtering of the lists was completed to exclude the grant beneficiaries in the subsidy list to avoid the duplication of data. In order to have a more comprehensive picture, it was recommended that $40 \%$ of the grant beneficiaries (1,000 farms) and $44 \%$ of the subsidy beneficiaries $(1,100$ farms in total) should be included in the sample. $16 \%$ of farms were set to include non-grant beneficiaries and subsidies. Since the list for non-grant beneficiaries could not be identified, it was decided that the identification of non-grant beneficiaries should be made according to the so-called "snowball". This means that they have identified non-beneficiaries of grants based on conversations with farmers with whom they conducted the survey. This way, the analysis of data does not exclude any category of farms that are of a particular importance in the farm structure. The survey was conducted with 2,500 farmers, from which 939 were from category "Grant", 1,166 from category "Beneficiary of Subsidies", and 195 from category "Not a Beneficiary of Subsidies" and 200 from category "Snowball". To have a comprehensive sample, all municipalities were weighed against the total number of farms in each region. Thus, based on the calculated weight, the number of farms in the sample of FSS according to each municipality was proportionally determined. This has resulted in the determination of farms being completely fair and without being influenced by any external factor. Farmers who have been selected to be interviewed for the survey 2014-2017 are those who own the farm and develop agricultural activities in it. From a large questionnaire for agriculture farm survey, for this paper, we selected only the questions which consisted of groups related to performance of the agriculture SMEs.

Tab 2. Sample distribution. Source: own calculation

\begin{tabular}{|l|c|c|c|}
\hline & $\begin{array}{c}\text { Total observation } \\
\text { (population) }\end{array}$ & Total chosen samples & $\begin{array}{c}\text { share in a total } \\
\text { sample of 2500 farms }\end{array}$ \\
\hline Total Grants & 1,525 & 939 & $36 \%$ \\
\hline Total Subsidies & 26,274 & 1,166 & $47 \%$ \\
\hline $\begin{array}{l}\text { Total Non-beneficiaries of } \\
\text { subsides }\end{array}$ & 1,081 & 195 & $8 \%$ \\
\hline Snowball & 28,880 & 200 & $8 \%$ \\
\hline Total & 2500 & $100 \%$ \\
\hline
\end{tabular}

Regarding the geographical coverage of the research, the whole rural territory of the Republic of Kosovo was covered with $94.3 \%$ including large numbers of small, micro and medium-sized enterprises, presented as per Table 3. 
Tab 3. Sample distribution to the Municipalities and Regions of Kosovo. Source: own compilation

\begin{tabular}{|c|c|c|c|c|}
\hline Municipality & Grants & Subsidies & Non- beneficiaries of subsidies & Total \\
\hline Decan & 19 & 30 & 5 & 54 \\
\hline Dragash & 15 & 15 & 6 & 36 \\
\hline Ferizaj & 33 & 50 & 8 & 91 \\
\hline Fushe Kosove & 10 & 15 & 2 & 27 \\
\hline Gjakove & 24 & 55 & 6 & 85 \\
\hline Gjilan & 26 & 32 & 6 & 64 \\
\hline Drenas & 34 & 39 & 7 & 80 \\
\hline Gracanice & 5 & 24 & 3 & 32 \\
\hline Hani i Elezit & 2 & 5 & 2 & 9 \\
\hline Istog & 73 & 71 & 12 & 157 \\
\hline Junik & 9 & 4 & 0 & 14 \\
\hline Kacanik & 9 & 21 & 5 & 35 \\
\hline Kamenice & 41 & 32 & 3 & 77 \\
\hline Kline & 14 & 47 & 8 & 70 \\
\hline Kllokot & 1 & 5 & 1 & 7 \\
\hline Municipality & Grants & Subsidies & Non- beneficiaries of subsidies & Total \\
\hline Leposaviq & 2 & 5 & 2 & 9 \\
\hline Lipjan & 30 & 67 & 8 & 105 \\
\hline Malisheve & 29 & 53 & 11 & 93 \\
\hline Mamushe & 26 & 5 & 1 & 32 \\
\hline Mitrovice & 24 & 26 & 3 & 53 \\
\hline Novoberde & 22 & 16 & 4 & 42 \\
\hline Obiliq & 10 & 22 & 4 & 37 \\
\hline Partesh & 0 & 2 & 2 & 4 \\
\hline Peje & 33 & 55 & 9 & 97 \\
\hline Podujeve & 58 & 84 & 16 & 158 \\
\hline Prishtine & 87 & 42 & 7 & 137 \\
\hline Prizren & 26 & 42 & 7 & 76 \\
\hline Rahovec & 112 & 145 & 15 & 271 \\
\hline Ranilluge & 1 & 3 & 1 & 4 \\
\hline Shterpce & 0 & 7 & 2 & 9 \\
\hline Shtime & 20 & 21 & 3 & 44 \\
\hline Skenderaj & 92 & 88 & 4 & 184 \\
\hline Suhareke & 52 & 56 & 9 & 117 \\
\hline Viti & 18 & 46 & 6 & 71 \\
\hline Vushtrri & 41 & 68 & 7 & 116 \\
\hline ZubinPotok & 1 & 1 & 1 & 3 \\
\hline Zvecan & 0 & 1 & 1 & 2 \\
\hline TOTAL & 1000 & 1300 & 200 & 2500 \\
\hline
\end{tabular}

In addition, a standardised questionnaire was drawn up to cover all interested data, in order to be more accurate and get detailed information and other features in the companies. The analysing of data was done with the SPSS Program (Statistical Package for Social Sciences) and the program on statistics R. 


\section{Results}

Increasing business capacity is a desire of every entrepreneur, but not all have concrete goals, plans ability, resources, knowledge, technology, etc., to increase their capacity. However, it is very important to observe and support the trend of capacity building for enterprises of all activities. Increasing the number of employees is also the goal of every entrepreneur which seeks to have continuous development of its work or production by implementing projects that help expand activities. In addition, the level of education of entrepreneurs is assumed to be an important determinant of the growth and development of agri SMEs in Kosovo. Inadequate professional education can affect sustainable development. The situation points out that the founders of agri SMEs in Kosovo do not have adequate education to manage and strengthen their enterprises, and thus they have to rely more on a system of "doing by looking"!

Table 4, presents the descriptive variables of chosen variables to run the regression model. From the total sample of 2500 respondents, 257 respondents have been removed with error calculation or misleading data. In total 2,243 respondents have been observed, which seems to be representative to run the model.

Tab 4. Descriptive Statistics of variables. Source: own compilation

\begin{tabular}{|l|c|c|c|c|c|}
\hline Variable & Obs & Mean & Std. Dev & Min & Max \\
\hline Total Annual Income & 2,243 & 22,487 & 99,462 & 1,025 & $3,008,600$ \\
\hline $\begin{array}{l}\text { Income from the sale of agricultural } \\
\text { products }\end{array}$ & 2,243 & 12,053 & 69,622 & 0 & $3,000,000$ \\
\hline $\begin{array}{l}\text { Income from Subsidies (direct } \\
\text { payments) }\end{array}$ & 2,243 & 1,598 & 5,793 & 0 & 190,000 \\
\hline $\begin{array}{l}\text { Salaries from non-agricultural } \\
\text { activities. }\end{array}$ & 2,243 & 5,147 & 63,561 & 0 & $3,000,000$ \\
\hline Pensions & 2,243 & 870 & 1,617 & 0 & 20,000 \\
\hline Social payments & 2,243 & 31 & 252 & 0 & 5,370 \\
\hline Remittances & 2,243 & 804 & 7,024 & 0 & 300,000 \\
\hline Income from other activities & 2,243 & 2,024 & 26,120 & 0 & 960,600 \\
\hline
\end{tabular}

Table 4 shows that Total Annual Income on average is 22,487 Euro with a minimum of 1,025 euro up to 3 million euro. The average annual earning of the agri small medium enterprise is the amount of 12,053 Euro from sales of agriculture products, while from subsidies they receive an amount of 1,598 Euro from subsidies. Salaries from non-agriculture activities average are 5,147 Euro, pensions average 870 Euro, social payments average 31 Euro, remittances (which are an important economic infusion in Kosovo) average 804 Euro and income from other activities average 2,024 Euro on average.

Regarding the infrastructure which is crucial to the success of SMEs as well as to the further economic and social development of the nation as a whole, one of the main questions was related to the very critical factor of electric power, which had been slow in being restored/extended in all parts of the country following the cessation of hostilities and the pre-hostility period of infrastructure neglect. Power outages have remained a persistent problem in parts of the country, and so it was important to include a question like "How often do you have a power outage?", and the data shows that 489 of respondents answered that they have never had power outage, only if it is due to weather condition and strong storms, while 2011 respondents answered that they have power outage during the average week. 
Tab 5. How long do power outage last? Source: own compilation

\begin{tabular}{|l|c|}
\hline Power outage duration & Number of respondents \\
\hline One hour & 790 \\
\hline Some minutes & 215 \\
\hline Some hours & 957 \\
\hline One day & 27 \\
\hline Longer & 22 \\
\hline Never & 489 \\
\hline Total & 2500 \\
\hline
\end{tabular}

Table 5 presents the length of time that power outages typically last in rural areas. It is still evident that SMEs face power outages in their home and business. To the questions whether the power outage affects the work of their enterprises or not, 1,347 answered that yes it does, while 664 respondents no, because they use an alternate power supply when the electricity is off. Although it is not in the focus of this paper, but the authors nevertheless note the stubbed and consistent challenge to widespread and sufficient economic development of all sectors in Kosovo that is presented by insufficient and unreliable electricity. Foreign Direct Investment, as well as domestic investment, is hampered by this problem.

The problem of poor availability of running water, which predates the period of hostilities and which has not been improved significantly since then, was also raised in a question, and 1965 of respondents answered yes, that they have access, while 535 answered no, they do not have access and instead they must use another owned supplies sources. Regarding the availability of sewage treatment, it is also still a problem in rural areas in Kosovo. From the total respondents, 1820 do not have access to sewage treatment while 680 have access to sewage treatment. Regarding the road infrastructure in the rural areas where the agri SMEs are dispersed, from the answers collected in our sample, we can see that 240 respondents were very dissatisfied and have not received or benefitted from any investments from the local or central government. It makes them very difficult to operate their SMEs under such circumstances. Conversely, 741 were very satisfied with the road network in their region. Figure 2 presents the evaluation level of respondents toward the roads network in their location.

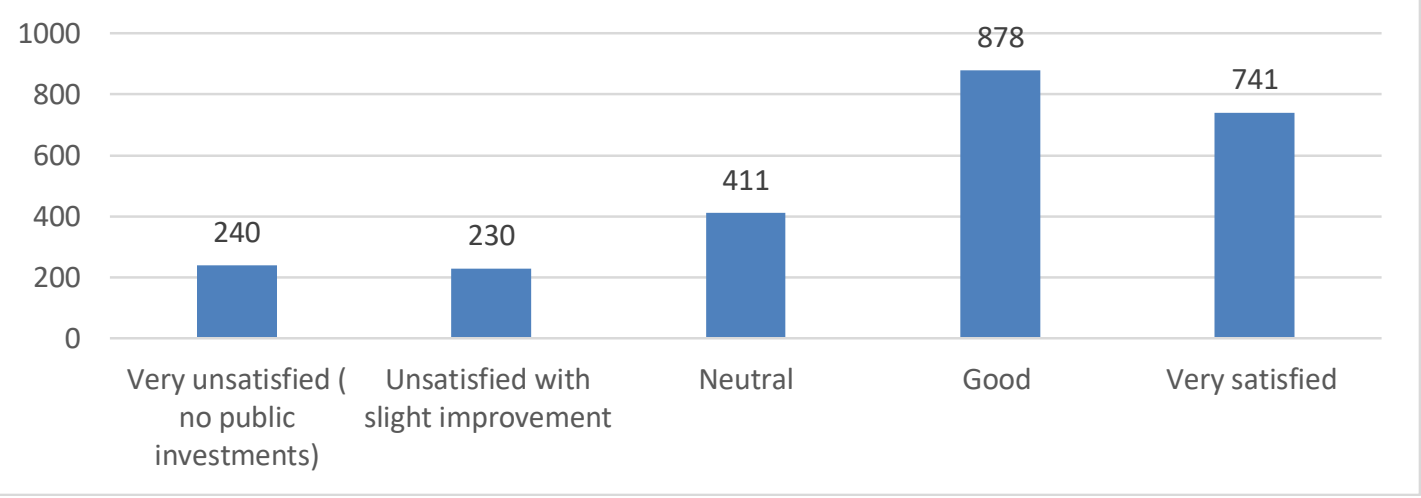

Fig 2. Roads network. Source: own compilation

As we can see from questions in Table 6, regarding the use of the internet, $96 \%$ of the respondents have internet connection in their area. This is in harmony with the findings of the national survey done by Kosovo ICT Association, namely that $96 \%$ of Kosovo households is currently connected to the internet. It can be stated that both rural and urban populations benefits from this critical resources. Laptops are the most frequent devices found in almost half of the Kosovo households (48\%), followed by a computer (39\%) ( ICT, 2019). In the near - and medium-term future, the agriculture sector should 
be able to use the internet for both technical training and capacity - building, as well as for market oriented purposes, as ways to strengthen and develop the production of their SMEs.

Tab 6. Usage of Internet. Source: own compilation

\begin{tabular}{|c|c|c|}
\hline & YES & NO \\
\hline Do you have access to internet connection? & $96 \%$ & $4 \%$ \\
\hline Do you use the internet for agricultural and business advices? & $74 \%$ & $26 \%$ \\
\hline Do you own a computer? & $69 \%$ & $31 \%$ \\
\hline Do you use computer for any business activities (software)? & $52 \%$ & $48 \%$ \\
\hline
\end{tabular}

$74 \%$ use the internet for business advices, while $26 \%$ do not take this opportunity. $52 \%$ use computer for business activities or any software related to their daily work, while $48 \%$ do not do it.

To the question whether any of a younger family member is ready to take over the business activities, $73 \%$ of respondents answered yes, while $13 \%$ is still not sure, and $14 \%$ answered no, which means not any of the younger family members are willing to continue business in the countryside.

To predict the value of the variable total amount of annual income in the family based on the value of other variables we used multiple regression analysis and the correlation:

$$
Y_{i}=\beta_{0+} \beta 1 \times 1+\beta 2 \times 2+\beta 3 \times 3+\beta 4 X 4+\beta 5 \times 5+\beta 6 \times 6+\beta 7 \times 7+e_{i}
$$

Dependend Variable: Annual Income

Independent Variables: Income from the sale of agricultural products; Income from Subsidies (direct payments); Salaries from non-agricultural activities; Pensions; Social payments; Remittances; Income from other activities.

Tab 7. Model Summary. Source: own compilation

\begin{tabular}{|c|c|c|c|}
\hline S & R-sq & R-sq(adj) & R-sq(pred) \\
\hline 59873.1 & $93.15 \%$ & $93.13 \%$ & $92.39 \%$ \\
\hline
\end{tabular}

Table 7 shows that the coefficient of determination R-squared is $93.15 \%$, which means that $93.15 \%$ of the change in 'Annual Income' (dependent variable) is explained by Income from the sale of agricultural products; Income from subsidies; Income from non-agricultural activities, salaries; pensions; social payments; revenue from remittances; Income from other activities (independent variables). $6.85 \%$ of the factors in the model are inexplicable.

Tab 8. Coefficients. Source: own compilation

\begin{tabular}{|l|c|c|c|c|c|}
\hline \multicolumn{1}{|c|}{ Term } & Coef & SE Coef & T-Value & P-Value & VIF \\
\hline Constant & 4237 & 1312 & 3.23 & 0.001 & \\
\hline Income from the sale of agricultural products & 0.9958 & 0.0183 & 54.50 & 0.000 & 6.96 \\
\hline Income from Subsidies (direct payments) & 1.0112 & 0.0783 & 12.91 & 0.000 & 6.96 \\
\hline Salaries from non-agricultural activities. & 0.9958 & 0.0199 & 50.07 & 0.000 & 1.00 \\
\hline Pensions & 0.342 & 0.566 & 0.61 & 0.545 & 1.00 \\
\hline Social payments & -0.72 & 5.00 & -0.14 & 0.885 & 1.00 \\
\hline Remittances & 0.946 & 0.180 & 5.26 & 0.000 & 1.00 \\
\hline Income from other activities & 0.9889 & 0.0484 & 20.42 & 0.000 & 1.00 \\
\hline
\end{tabular}


Based on the model for the regression $Y_{i}=\beta_{0+} \beta 1 \mathrm{X} 1+\beta 2 \mathrm{X} 2+\beta 3 \mathrm{X} 3+\beta 4 \mathrm{X} 4+\beta 5 \mathrm{X} 5+\beta 6 \mathrm{X} 6+\beta 7 \mathrm{X} 7+e_{i}$; Annual income $=4237+0.9958$ (income from the sale of agricultural products) +1.0112 (income from subsidies) +0.9958 (income from non-agricultural activities) +0.342 (income from pensions salaries) - 0.72 (income from social payments) +0.946 (income from remittance) +0.9889 (income from other activities).

From this we understand that significant factors having effect on the annual income of agri SMEs are the followings: Income from the sale of agricultural products; Income from subsidies; Income from non-agricultural activities, salaries; remittances; Income from other activities.

Where with the increase of 'income from the sale of agricultural products' per unit, 'Annual income' increases by $0.9958 €$. With the increase of 'Income from subsidies' for one unit, 'Annual income' increases by $1,0112 €$. Further, with the increase of 'Income from non-agricultural activities, salaries' per unit, 'Annual revenues' increase by 0.9958 .

Tab 9. Correlation. Source: own compilation

\begin{tabular}{|c|c|c|c|c|}
\hline \multirow{3}{*}{$\begin{array}{l}\text { Income from the sale } \\
\text { of agricultural products }\end{array}$} & $\begin{array}{l}\text { Annual } \\
\text { Income }\end{array}$ & $\begin{array}{l}\text { Income from the sale } \\
\text { of agricultural } \\
\text { products }\end{array}$ & $\begin{array}{l}\text { Income from } \\
\text { Subsidies (direct } \\
\text { payments) }\end{array}$ & $\begin{array}{l}\text { Salaries from non- } \\
\text { agricultural activities }\end{array}$ \\
\hline & 0.920 & & & \\
\hline & 0.000 & & & \\
\hline \multirow{2}{*}{$\begin{array}{l}\text { Income from Subsidies } \\
\text { (direct payments) }\end{array}$} & 0.876 & 0.925 & & \\
\hline & 0.000 & 0.000 & & \\
\hline \multirow{2}{*}{$\begin{array}{l}\text { Salaries from non- } \\
\text { agricultural activities }\end{array}$} & 0.261 & -0.003 & -0.001 & \\
\hline & 0.000 & 0.891 & 0.957 & \\
\hline \multirow{2}{*}{ Pensions } & 0.000 & -0.007 & -0.007 & 0.017 \\
\hline & 0.992 & 0.737 & 0.708 & 0.382 \\
\hline \multirow{2}{*}{$\begin{array}{l}\text { Social Payments, non- } \\
\text { agricultural activities }\end{array}$} & -0.006 & -0.005 & -0.004 & -0.005 \\
\hline & 0.760 & 0.796 & 0.859 & 0.812 \\
\hline \multirow{2}{*}{ Remittances } & 0.032 & 0.003 & 0.000 & 0.004 \\
\hline & 0.109 & 0.892 & 0.986 & 0.849 \\
\hline \multirow{2}{*}{$\begin{array}{l}\text { Income from other } \\
\text { activities }\end{array}$} & 1.116 & 1.010 & 0.001 & 0.004 \\
\hline & 0.000 & 0.615 & 0.952 & 0.857 \\
\hline
\end{tabular}

Tab 10. Tables content: Pearson Correlation and P-value. Source: own compilation

\begin{tabular}{|c|c|c|c|}
\hline \multirow{3}{*}{$\begin{array}{c}\text { Social Payments } \\
\text { from non-agricultural activities }\end{array}$} & Pensions & Social Payments & Remittances \\
\cline { 2 - 4 } & -0.000 & & \\
\cline { 2 - 4 } & 0.982 & & \\
\hline \multirow{2}{*}{ Remittances } & 0.016 & -0.006 & 0.012 \\
\cline { 2 - 4 } & 0.429 & 0.756 & 0.548 \\
\hline \multirow{2}{*}{ Income from other activities } & -0.015 & 0.006 & 0.780 \\
\hline
\end{tabular}

Table 9 and 10 show us that there is significant relationship between the 'Income from the sale of agricultural products' and 'Annual income', with a value of $P(0.000)$ and Correlation (0.920). There is also a strong positive correlation between the 'Income from the sale of agricultural products' and 'Income from subsidies. Furthermore, there is also a significant relationship between the 'Annual income' and 'Subsidy income'. 


\subsection{Descriptive Data of SMEs}

Data from FSS has been analyzed. The analysis included the following steps: i) the identification of the data which is regularly sourced directly from farmers and those data which is estimated or calculated based on data of previous years, ii) the evaluation of the significance of the sample used for FSS and of the strata included in the sample, to assess which data subsets can be used to analyze a specific cluster, such as agricultural firms located in a certain municipality or agricultural firms specialized in a certain production and, iii) the assessment of the possibility of processing automatically the data (it was possible only after exporting data from MS Excel to formats suitable for database software)

The FSS dataset is important because, in spite of its limitations, it is the most comprehensive primary dataset yearly collected in the whole country and the only source for some information, such as the availability of farm machinery at farm level.

\subsection{Outcomes of the models}

According to the collected data and to the model in its present form, the outcome of the production cost and profitability analyses can be summarized as follows:

Enterprises cultivating cereal crops are profitable under the present price system. This statement is valid for winter wheat, maize in grains and maize for silage. Data on labour input have been confirmed in the validation phase, but are probably underestimated, as they are lower than in most production cost analyses performed in other countries of the region and in EU member states. Irrigated crops give more profit (with higher costs), but the main benefit of irrigation is related to the reduction of risk related to adverse weather conditions.

Apple production is profitable but less than generally thought. When accounting for the amortizations of the investment made for orchard plantations (on 20-years economic life) and for farm family labour at market prices, the multi-annual cash flow turns positive after seven to eight years, depending on marketable yields (i.e., the quantity of apples actually sold after considering losses and unsold production). The marketable yields of 35 to 40 tons/ha or more, which are commonly reported are hardly compatible with a reported average price of $0.3 \mathrm{Euro} / \mathrm{kg}$ and with the scarcity of proper storage facilities, (which this paper has previously cited as a serious challenge to increased production/distribution of agriculture products), which increases losses. In the model, a marketable yield of 28 to 30 ton/ha (equivalent to 28 to 35 ton/ha of harvested apples) was considered.

Grape growing for wine production is not profitable, especially under present market conditions, characterized by the high price of inputs and low prices of grapes for wine. When calculating all costs (including family work) at market prices, there is no profit, even before amortizations. The low sale price of grapes is based on the combination of factors, including relatively low quality of grapes and oversupply of wine in international markets (the price of many wines with Denomination of Origin in EU member states are scoring record lows). The investment cost for a new vineyard is higher than in most countries of the region. Further analysis of the investment costs is recommended but it is not expected to change the overall picture.

Cattle milk production on a small scale is not profitable. The main issue is the average milk yield of cows which is too low, considering the amount given and the feed intakes. This is probably due to a combination of the relatively low quality of feed and insufficient genetic potential of cows ${ }^{8}$.

A second important issue regarding milk production is that costs calculations have much affected the self-production of some inputs as compared with purchasing of all the inputs at market price. If all inputs are calculated at market price, the activity is not profitable and the income does not cover

\footnotetext{
8 It could also be related to excessive exploitation of cows with good genetic potential, whose output steeply decline in recent years, due to inadequate feeding.
} 
even the variable costs; when part of the animal feed is produced in the farm and cows at the end of economic life are replaced with heifers raised in the farm, the overall financial pictures are much better; This situation is common in many countries of the World (e.g. in Albania), where milk production turns profitable only if the animal feed is produced at farm level (Imami, D. Zhllima, E. Merkaj, E. Catherine Chan-Halbrendt, C. Canavari,M., 2016).

In Kosovo, if part of the feed is self-produced and replacement heifers come from the farm, it is possible with 10 cows (for example) to obtain a contribution margin of about 4,500 to 6,000 Euro per year, to pay for family work and amortizations. The value of amortization is about 3,500 Euro/year if cows are replaced with heifers raised in the farm; this leaves 1,000 to 2,500 Euro to pay the family work, which is something but is still far from the market value of the work provided by family members, which scores almost 7,300 Euro/year.

Another important aspect is the economies of scale: with 20 heads and self-production of some inputs (part of animal feed and replacement heifers), it is possible to pay for amortizations at replacement cost, family work at market prices and still get a profit.

Sheep milk production is profitable, but market constraints are hampering the viability of the business. Sheep breeders have little cash costs, but cash revenues are low, too, so that in small breeding farms (50 ewes) more than $50 \%$ of the total benefit comes from the value of food produced for selfconsumption in the family farm. Rewards are much better for farmers having a flock of 200 ewes, but in this case, marketing problems particularly for cheese and sheep milk are making the business more difficult and riskier. Difficult marketing prospects related to weak demand for cheese made with sheep milk may explain why several breeders in the sample are changing the focus of their activity from milk-production oriented to meat-production oriented, in spite of an overall positive balance between costs and revenues when the entire product is sold.

\section{Discussion}

As a conclusion, Kosovo's agri SMEs have the potential of being one of the engines of growth over the short to medium term and to help the recovery of the country's agriculture sector and to reach its pre-war status of self-sufficiency and contribution to exports. Building on recent successes in increasing the productivity of the agricultural sector and agri-processing-including the implementation of targeted reforms and policies aimed at facilitating the formalisation of agricultural activities and farmers' connections to markets in Kosovo and abroad-could help to provide the rural population with considerably improved economic and social development opportunities. This requires close collaboration with all actors and institutions (certainly including the public sector) involved in this process, to help the agriculture sector to "catch up" to production methods employed elsewhere and take full advantage of the assistance offered by the EU and other development partners.

Likewise, the results of the research show that the performance of agri SMEs varies from economic and social welfare, efficient use of capacities, an increase of independence and free capital investment. The main difficulties that the businesses face are related to unfair competition, finding consumers and loans, the limited access to capital and unfavourable fiscal policies. To be more specific, the main findings of the production cost and profitability analyses can be summarized as follows:

The profitability of productions is generally affected by low yields of products, technical challenges and/or high costs of production and marketing/distribution and/or low sale prices, which translates into reduced competitiveness; as a result, many labour-intensive productions show low profitability or a loss when family labour and self-produced inputs are calculated at market prices. This is generally due to a combination of factors (economies of scale, marketing system, quality of inputs etc.). This paper can be considered unique because it is the first to present that this gap of competitiveness can be measured. For example, in the case of cattle milk production, low milk yields 
as compared with feed intakes can be caused by a number of factors (breed, quality of feed etc.), but the final result is that the production is scarcely competitive and is sustainable mostly because of the profitability of the upstream segments of the activity (in-farm production of animal feed and use of own calves for replacement of old cows).

The share of amortization on total costs for fruit growing and animal production is high if investments are calculated at replacement cost, scoring between 16\% (sheep milk production) and $21 \%$ (grape growing for wine production) of total costs. This is another aspect of the low productivity of factors, which is related to the investment costs, which are comparable or higher than in most Western countries (e.g., cost of saplings, cost of farm machinery), while revenues are smaller, and to the lack of economies of scale. The share of amortization on total costs is obviously lower for cereal crops (around 11\%) and much higher (66\%) for alfalfa production.

The cost/opportunity of using farm labour and machinery is much lower than the market price, due to the lack of alternative opportunities: this factor explains why farmers nevertheless feel positive about productions whose profitability is disputable at best; this is seen, for example, in the case of cattle milk, whose profitability is negative, if all factors are calculated at market price and amortizations are properly accounted, but is considered positively by farmers, as it allows to use many resources already available in the farm (family labour, land, previously existing fixed assets and machinery) and generates a relatively good cash flow, even if it does not allow to pay for the use of farm family assets at market prices ${ }^{9}$.

Access to market has an impact on farmers' sentiment higher than total profitability: sheep milk production is more profitable than cattle milk production, but milk breeders are more positive about their prospects, as demand for cheese made by sheep milk is stagnant or decreasing, while demand for cattle milk is growing. Consumer preferences and market trends of agri-food products are still scarcely investigated in Kosovo.

\section{Conclusions}

Despite the positive results presented in chapter 4, in our view, this is because the improvement in farm viability, competitiveness and job creation in agri SMEs requires simultaneous and coordinated actions on the overall production system, on the agricultural services, input and output markets and the introduction and dissemination of knowledge and innovation.

The study also identified the need to shift the location of milk, meat and egg production from predominantly small-scale "closed" systems to medium-sized commercial farms that are compliant with National and EU food safety, animal welfare and environmental standards.

Based on parameters provided by the Green Reports, FADN and Kosovo Agency for Statistics, the authors can confirm that the support has been targeted at a small group of farm businesses that could have the potential to use the grant aid to change the physical structure of their business, negotiate favourable terms with targeted buyers and improve the level and quality of their output to meet the buyers requirements.

Finally, it should be noted that there are significant gaps and weaknesses in the value chains that can be partially addressed by providing grant aid for investments are crucial. For example, grant aid for the establishment of produce collection centres could help small-scale producers to compete on quality and negotiate better terms with buyers but the organisation of those small producers and building their capacity to manage collection centres also requires social facilitation, trust building, training and knowledge transfer.

\footnotetext{
${ }^{9}$ In the case of cattle milk and present system of prices, farmers would enjoy a much higher profit if selling animal feed and two-year heifers instead of producing and selling milk, but they will find it extremely difficult or even impossible to sell these products, while they have no problems in selling the milk.
} 
Improvement in agri SMEs viability, competitiveness and job creation in agri SMEs will require simultaneous and coordinated actions on all the barriers, an example being the need for better organisation of small-scale and intermittent suppliers. This is not only to improve their bargaining power but also to improve the quality and consistency, traceability, safety and presentation of products to the point where it can compete with the imports on the supermarket shelves.

\section{Acknowledgments}

We are grateful to the MAFRD Economic Analysis Department who sponsored the project 'Capacity development of the Department for Economic Analysis and Agricultural Statistics on research development, data collection, and structuring and data analysis, and special thanks go to Delvina Hana and to the Department of Economic Analysis and Agricultural Statistics (DEAAS) staff for their contribution to design and implement the survey. Another very special thanks go to Mr. Stephen Leeds for proofreading the paper and for his very valuable professional contribution. Disclaimer: Views expressed in this paper do not represent the views of the Ministry of Agriculture, Forestry, and Rural Development of Kosovo.

\section{Academic references}

[1] Alarcón, S. \& Sánchez, M. (2013). External and internal R\&D, capital investment and business performance in the Spanish agri-food industry. Journal of Agricultural Economics , 64(3), 654675. DOI: 10.1111/1477-9552.12015.

[2] Dixon, R., Lim, G. C. \& van Ours, J. C. (2016). Revisiting Okun's Relationship [IZA Discussion Paper No. 9815]. Bonn: Forschungsinstitut zur Zukunft der Arbeit.

[3] Edward, S., Knotek, II. (2007). How Useful is Okun's Law? Kansas: Federal Reserve Bank of Kansas City.

[4] Erjavec, E. \& Lovec, M. (2017). Research of European Union's Common Agricultural Policy: disciplinary boundaries and beyond. European Review of Agricultural Economics, 44(4), 732754. DOI: 10.1093/erae/jbx008.

[5] Erjavec, E., Tina, V., Rednak, M., Ciaian, P. \& Lazdinis, M. (2020). Agricultural policies and European Union accession processes in the Western Balkans: aspirations versus reality. Eurasian Geography and Economics. DOI: 10.1080/15387216.2020.1756886.

[6] ERP (2016). KOSOVO ECONOMIC REFORM PROGRAM 2017-2019. Prishtine: Government of Kosovo.

[7] ERP (2018). Kosovo's Economic Reform Program 2018-2020. Brussels: European Commission.

[8] FAO (2013). Enabling environments for agribusiness and agro- industries development Regional and country perspectives. Rome: FAO.

[9] Gjokaj, E., Leeds, S., Halimi, K. (2018). The impact of fi nancial support program in creation on farm jobs,. Bulgarian Journal of Agricultural Science, 24(6), 933-941.

[10] Gjokaj. E, Halimi, K., Xhabali, V., Imami, D., Gjonbalaj, M. (2017). FRUITS VALUE CHAIN AND DISTRIBUTION CHANNELS IN KOSOVO. Bulgarian Journal for Agriculture science, 23 (No 1) 2017, 22-30.

[11] Imami, D., Zhllima, E., Merkaj, E., Catherine Chan-Halbrendt, C., Canavari, M. (2016). Albanian Consumer Preferences for the use of Powder Milk. Thessaloniki: AGRICULTURAL ECOOMICS REVIEW. 
[12] KAS (2015). AGRICULTURE CENSUS IN THE REPUBLIC OF KOSOVO. Prishtine: Kosovo Agency of Statistics.

[13] KAS (2012). Kosovo Population and Housing Census 2011. Prishtine: Kosovo Agency of Statistics.

[14] Kostov, P., Davidova, S., Bailey, A., Gjokaj, E., Halimi, K. (2020). Can Direct Payments Facilitate Agricultural Commercialisation: Evidence from a Transition Country. The Agricultural Economics Society: Journal of Agricultural Economics.

[15] MAFRD (2013). Agriculture and Rural Development Programm. Prishtine: 2014.

[16] MAFRD (2013). Agriculture and Rural Development Programm 2014-2020. Prishtine: Ministry of Agriculture, Forestry and Rural Development.

[17] MAFRD (2019). Green Report Kosovo 2019. Prishtine: Ministry of Agriculture, Forestry and Rural Development.

[18] McAdam, M., McAdam, R., Dunn, A. \& McCall, C. (2016). Regional horizontal networks within the SME agri-food sector: An innovation and social network perspective. Regional Studies, 50(8), 1316-1329.

[19] Muriqi, S., Baranyai, Z., Fekete-Farkas, M. (2020). Comparative Analysis of SocioDemographic, Agricultural and Economic Factors of Cooperative \& Non-cooperative Farmers in Kosovo. ProQuest, Basel, $\mathrm{CH}$.

[20] Muriqi, S., Fekete-Farkas, M. \& Baranyai, Z. (2019). Drivers of cooperation activity in Kosovo's agriculture. Agriculture (Switzerland), 9(5). https://doi.org/10.3390/agriculture9050096.

[21] Panasyuk, M. V., Safiullin, L. N., Gafurov, I. R., Safin, A. R. (2014). Role of Small Businesses in the Agricultural Sector of the Region. Mediterranean Journal of Social Sciences, Vol 5 No 28.

[22] UNDP (2013). Rural Household Survey: Analysis UNDP, 2012. Prishtine: UNDP office in Prishtina.

[23] Weidinger, C., Fischler, F., Schmidpeter, R. (2014). Sustainable Entrepreneurship: Next Stage of Responsible Business. Berlin: Springer-Verlag Berlin Heidelberg.

Other sources

[24] ICT (2019). Internet Penetration and usage in Kosovo. Prishtina: Association Kosovo ICT \& KANTARA.

[25] EC (2018). COMMISSION STAFF WORKING DOCUMENT Kosovo* 2018 Report. Strasbourg: European Commission. 